\title{
Identifying and Understanding High Growth Firms in the Pakistani Textile and Apparel Sectors ${ }^{*}$
}

\section{Waqar Wadho** and Azam Chaudhry}

\begin{abstract}
In this article, we investigate the distinguishing features of fast growing firms in the Pakistani textile and apparel sectors. We find that the distribution of firm growth-both in terms of employment and sales - is very heavily skewed toward the right-tail, confirming earlier findings that firm growth is generated by a very small number of firms. We found that small and young companies grow faster and generate higher employment. We also used various indicators of a firm's innovation behavior and found that more innovative firms grow faster. Our results suggest that it is not the possession of individual attributes, but rather a combination of particular firm attributes that defines fast growing firms. Specifically, we found that the blend of being small, young and innovative explains the fast growth in firms. on overall these companies also create more jobs.
\end{abstract}

Keywords: Firm growth, employment creation, young innovative companies, textiles, Pakistan.

\section{JEL Classification: O12, L26.}

\section{Introduction}

The critical role of innovation in the survival and expansion of firms has been emphasized in the literature as far back as Schumpeter (1942). In recent years, there has been significant amount of work looking at the role of various types of innovation in firm-level growth and more recently there has been a growing interest in young, innovative and fast-growing firms by both entrepreneurship scholars and policymakers. Fast growing firms make considerable contributions to economic growth and also generate employment opportunities. This is especially important in the case of

\footnotetext{
* The authors acknowledge financial support from the International Growth Center (1-VRCVPAKVXXXX-89222) and the Lahore School of Economics for the project "Measuring Innovation in the Textiles Sector of Pakistan" for the data used to conduct this study. We would like to thank the Bureaus of Statistics of Punjab and Sindh, for their assistance.

** Corresponding: Lahore School of Economics, Barki Road, Lahore, Pakistan. Email: w.wadho@lahoreschool.edu.pk
} 
developing countries where the demographics are such that a large number of young people are entering the labor market every year. Firm growth is also cardinal to the structural transformation of an economy and historically, the manufacturing sector has been considered as driver of economic growth. The expansion of the manufacturing sector also helps increase the employment absorption capacity of the economy. However, the literature from a wide range of countries shows that firm growth is highly uneven, and the majority of employment is created by a very small number of firms, termed 'gazelles' or high growth firms (HGF) (Wadho, Goedhuys, \& Chaudhry, 2019; OECD, 2007). Given the key role of fast growing firms in fostering employment generation, an understanding of the mechanisms behind their growth patterns in developing countries is crucial.

The firm growth literature provides some important correlates of employment creation and growth. Younger and smaller firms are shown to grow faster than older and larger firms (Coad \& Rao, 2008; Coad, 2009; Coad, 2016). Another important aspect of firm growth is related to innovation. To survive and grow in a competitive industry, a firm needs to innovate through the introduction of new products and processes. Innovation is indeed found to be conducive to employment creation and firm growth (Wadho, Goedhuys, \& Chaudhry, 2019; Audretsch et al., 2014). Moreover, in recent years the focus has shifted toward understanding what is the combination of firm attributes associated with superior performance. Specifically, the questions that have attracted considerable attention from the scholars include: How do firm size and age interact with innovation? And does this innovation lead to superior firm performance? A number of recent studies indeed show that small young and innovative companies exhibit superior growth performance and create disproportionate jobs (Wadho, Goedhuys, \& Chaudhry, 2019; Czarnitzki \& Delanote, 2013; Pellegrino et al., 2011; Schneider \& Veugelers, 2010; Veugelers 2009).

Though the literature has focused first on the role of innovation in firm-level growth, much of this work has been based on analysis of data from developed economies. Also, the analysis of managerial innovations is far more recent in the analysis of firm-level innovations and much of the measurement of these types of innovations have also occurred in the context of developed economies. In this study, we attempt to fill these gaps by looking at the role of various types of innovations (including technological and managerial innovations) on firm growth in the context of a developing country. What makes this analysis even more novel is that it focuses on a specific sector (textiles) in a developing country (Pakistan) which is particularly critical from a macroeconomic growth perspective. 
This study complements Wadho, Goedhuys, and Chaudhry (2019) by identifying the characteristics of fast-growing firms, and by supplementing their evidence with two case studies of young innovative companies, as well as Wadho and Chaudhry (2018) by providing evidence on the growth impact of technological in addition to managerial innovation.

We present some of the results of a unique innovation survey conducted in 2015 with the textile (textile and apparel) manufacturers in Pakistan. The survey asked manufacturers about their innovation activities and the introduction of various types of innovations (product, process, managerial and marketing) for the period 2013-2015. Textiles is Pakistan's major manufacturing sector, contributing one-fourth of industrial value added, employing 40 percent of the industrial labor force, and contributing 56 percent to national exports.

We find that small and younger firms grow faster and create more absolute jobs and that innovation is conducive to job creation, where job creation is measured by employment growth. However, and more importantly, we found that this superior growth performance is associated with the combination of being small, young and innovative. Furthermore, much of the literature on firm-level innovation has been made up of empirical studies analyzing either cross-sectional or panel datasets to determine the causes and effects of innovation. But in much of this empirical work, there has been a lack of focus on how and why specific firms have innovated and the impact of this innovation. In order to add to the existing literature by looking at specific cases of companies that are young and especially innovative, we held in-depth interviews with two of the young innovative companies (YICs) to learn about the nature and novelty of innovation in the sector and we assessed the entrepreneurs' views on the role of their innovation for corporate success. From this complementary analysis we find success lies with the YICs' focus on introducing new products into the international market. YICs consider an in-house R\&D department that works in collaboration with other departments (such as marketing and procurement) to introduce new products combining fashion with performance as critical for survival and growth. Equally important is investing in processes with modernized machinery for the production of new products. While being part of a larger group seemed important in terms of getting access to business networks and initial success, new products with improved processes along with improved managerial practices are considered the most essential ingredients for the persistence of high growth. 
The layout of the study is as follows: In the next section we discuss the theoretical framework. In Section 3, we explain the innovation survey and present descriptive statistics. In Section 4 we discuss some of the correlates of growth while Section 5 contains some qualitative case studies. Finally, Section 6 concludes.

\section{Theoretical Framework}

The theoretical underpinnings of our analysis are based on the idea that both local and international competition can impact demand for products, prices of products and markups and this in turn implies that firms need to innovate (either through new products and process or through managerial innovations) in order to survive (Schumpeter, 1942). Beyond survival, firms must also innovate in order to grow both in terms of sales and employment (Audretsch et al., 2014), so one factor that impacts firm growth is the level of innovation. Furthermore, the literature has found that smaller and younger firms tend to be more flexible in their ability to innovate (since innovation requires changes in products and processes) and this in turn increases their chances of surviving and growing (Wadho, Goedhuys, \& Chaudhry, 2019; Coad, 2009; Quatraro \& Vivarelli, 2014). So, in theory smaller and younger firms have a greater chance of having higher innovation which in turn can have an impact in their levels of sales and employment growth.

We use our unique dataset to catagorize textile and garment manufacturers based on their size and age and then see if the smaller, younger firms experience higher growth.

\section{Innovation Survey and Firm Level Statistics}

\section{Description of Survey}

In 2015, we surveyed 614 textile and wearing apparel manufacturers from the Punjab and Sindh provinces of Pakistan. The textile and wearing apparel sector is defined as all manufacturing firms classified under Sections 13 and 14 of the Pakistan Standard Industrial Classification, PSIC 2010. We used the Directory of Industries as the initial sampling frame. This frame was then updated with the support of the respective bureaus of statistics in Sindh and Punjab.

For this type of survey, the Oslo manual (OECD, 2005) recommends stratified random sampling where the strata can be based on the size of firm, 
principal activity of the business, geographic location of the firms, etc. Due to the limited information available in our frame, we could only stratify our sample based on the geographic location of firms. We drew a stratified random sample which was representative firstly at the provincial level and then at the district/regional level. The total population of the textiles and wearing apparel manufacturers in Punjab and Sindh provinces is 4205 units, and our sample size of 614 is around 15 percent of the population.

The survey questionnaire was designed on the basis of the Oslo manual (OECD, 2005) and its recommendations for developing countries. The core questionnaire related to innovation was similar to the Community Innovation Surveys (CIS) of Europe. Apart from the standard modules on technological (product and process) innovation, the questionnaire included modules on non-technological (organizational and marketing) innovation, competition, and information communication and technologies. The survey was conducted between August and October 2015 and innovation related questions were asked for the previous three years, 2013-2015. The survey response rate was 70 percent and a total of 431 firms voluntarily participated in the survey. The majority of the nonrespondents were firms which did not exist or were permanently closed at the time of survey (139 firms out of a total 183 non-respondents). Out of the 431 respondents, there were firms who did not report their annual turnover due to confidentiality issues; however, we did not find systematic refusal based on firm characteristics or geographic location. In order to ensure that the data is suitable for estimations, we remove all firms not reporting turnover in 2015 and this reduced our sample to 377 firms.

\section{Descriptive Statistics}

In this section we present some of the characteristics of the firms in our survey. We start with some of the basic firm-level descriptive information and then look at the distribution of employment growth and sales growth of the firms in our sample.

Table 1 gives an overview of the definition of variables used and presents some summary statistics. 


\section{Table 1: Description and summary statistics of the variables}

\begin{tabular}{|c|c|c|}
\hline Variable & Definition & $\begin{array}{c}\text { Mean } \\
\text { (Std Dev) }\end{array}$ \\
\hline $\begin{array}{l}\text { Employment } \\
\text { growth }\end{array}$ & $\begin{array}{l}\text { Natural logarithm of employment in } 2015 \text { minus natural } \\
\text { logarithm of employment in } 2013\end{array}$ & $\begin{array}{l}0.10 \\
(0.86)\end{array}$ \\
\hline Sales growth & $\begin{array}{l}\text { Natural logarithm of tunover in } 2015 \text { minus natural } \\
\text { logarithm of turnover in } 2013\end{array}$ & $\begin{array}{c}0.95 \\
(4.16)\end{array}$ \\
\hline Age & $\begin{array}{l}\text { Firm age measured as the natural logarithm of years in } \\
2015 .\end{array}$ & $\begin{array}{c}21.7 \\
(13.9)\end{array}$ \\
\hline $\begin{array}{l}\text { Product } \\
\text { Innov. }\end{array}$ & $\begin{array}{l}=1 \text { if a firm introduced new or significantly improved } \\
\text { products during 2013-15 that were at least new to the firm. }\end{array}$ & 0.334 \\
\hline $\begin{array}{l}\text { Process } \\
\text { Innov. }\end{array}$ & $\begin{array}{l}=1 \text { if a firm implemented a new or/and significantly } \\
\text { improved production process, distribution method, } \\
\text { or/and supporting activity during the three years 2013-15. }\end{array}$ & 0.406 \\
\hline $\begin{array}{l}\text { Managerial } \\
\text { Innov. }\end{array}$ & $\begin{array}{l}=1 \text { if a firm implemented a new organizational method in } \\
\text { its business practices, workplace organization, or external } \\
\text { relations during previous the three years 2013-15. }\end{array}$ & 0.302 \\
\hline Tech. Innov. & $\begin{array}{l}=1 \text { if a firm introduced product and/or process innovation } \\
\text { during } 2013-15 \text { that were at least new to the firm. }\end{array}$ & 0.496 \\
\hline Cont. R\&D & $\begin{array}{l}=1 \text { if a firm performed } R \& D \text { on continuous basis during } \\
2013-15 \text {. }\end{array}$ & 0.241 \\
\hline R\&D Intensity & $\begin{array}{l}\text { Natural logarithm of total expenditure on innovation in } \\
\text { 2015. Total expenditure is a sum of expenditure on (i) in- } \\
\text { house R\&D, (ii) external R\&D, (iii) acquisition of machinery, } \\
\text { equipment and software, (iv) acquisition of external } \\
\text { knowledge, and (v) training for innovative activities. }\end{array}$ & $\begin{array}{c}7.87 \\
(10.0)\end{array}$ \\
\hline $\mathrm{YIC}_{1}$ & $\begin{array}{l}=1 \text { if less than } 50 \text { workers, less than } 10 \text { years old, and } \\
\text { technological innovation in 2013-15. }\end{array}$ & 0.040 \\
\hline $\mathrm{YIC}_{2}$ & $\begin{array}{l}=1 \text { if less than } 50 \text { workers, less than } 10 \text { years old, and } \\
\text { invested at least } 5 \% \text { of turnover in innovation in } 2015 .\end{array}$ & 0.019 \\
\hline $\mathrm{YIC}_{3}$ & $\begin{array}{l}=1 \text { if less than } 50 \text { workers, less than } 10 \text { years old, and } \\
\text { continuous R\&D in 2013-15 }\end{array}$ & 0.020 \\
\hline $\begin{array}{l}\text { Human } \\
\text { capital }\end{array}$ & $\begin{array}{l}\text { Natural logarithm of the total number of workers in } 2015 \\
\text { with a university degree or/and professional diploma. }\end{array}$ & $\begin{array}{l}1.76 \\
(2.23)\end{array}$ \\
\hline Exports $_{2013}$ & $\begin{array}{l}\text { Natural logarithm of exports as a share of turnover in } \\
2013 .\end{array}$ & \\
\hline
\end{tabular}

Source: Authors' Calculations. 
Table 2 presents the descriptive statistics on firm size, firm sales, firm age, product innovation, process innovation, continuous $R \& D$ and R\&D intensity.

\section{Table 2: Firm Characteristics}

\begin{tabular}{lcccccccc}
\hline & \multirow{2}{*}{ Obs } & \multirow{2}{*}{ Empl } & \multirow{2}{*}{ Sales } & \multirow{2}{*}{ Age } & $\begin{array}{c}\text { aProduct } \\
\text { Inn. }\end{array}$ & $\begin{array}{c}\text { aProcess } \\
\text { Inn. }\end{array}$ & $\begin{array}{c}{ }^{a} \text { Cont. } \\
\text { RED }\end{array}$ & $\begin{array}{c}{ }^{b} \text { RED } \\
\text { Intensity }\end{array}$ \\
\hline Total & 377 & 348 & 731 & 21.7 & 33.4 & 40.6 & 24.1 & 9.3 \\
Apparel & 71 & 509 & 1110 & 20.1 & 56.3 & 52.1 & 45.1 & 11.7 \\
Textile & 306 & 311 & 644 & 22.1 & 28.1 & 37.9 & 19.3 & 8.4 \\
\hline
\end{tabular}

Source: Authors' Calculations.

Note: Firm Sales are given in Millions Rupees. a) as a percentage of firms, b) as a percentage of total turnover in 2015 for only those firms who reported investing in innovation.

Overall, one-third of the firms reported introducing new products and around forty percent reported introducing new processes during the 2013-15 period. In terms of innovation efforts, around one-fourth of firms reported that they have an in-house R\&D department and that they conduct R\&D on continuous basis. Firms who reported investing resources on innovation, spent on average nine percent of their sales on such activities in 2015.

There are also some noticeable differences between the two subsectors. On average, firms in the apparel sector employ more than the textile sector, their sales are much higher and are relatively younger than firms in the textile sector. Firms in the apparel sector are also more innovative. On average, there are twice as many firms in apparel that introduced new products as compared to textiles. Likewise, the percentage of firms introducing new processes is also higher in the apparel sector. In addition, apparel firms outperform the textile sector in terms of expenditures as a percentage of turnover on innovation activities as well as performing $R \& D$ on a continuous basis.

\section{Employment Growth in Firms}

Moving on to employment, Figures $1 \mathrm{a}, 1 \mathrm{~b}$ and $1 \mathrm{c}$ show the distribution of employment growth (2013-15) in the overall sample, apparel sector, and the textiles sector, respectively. ${ }^{1}$

\footnotetext{
${ }^{1}$ Where the density refers to the kernel density estimate.
} 
Figure 1a: Employment Growth (2013-2015)

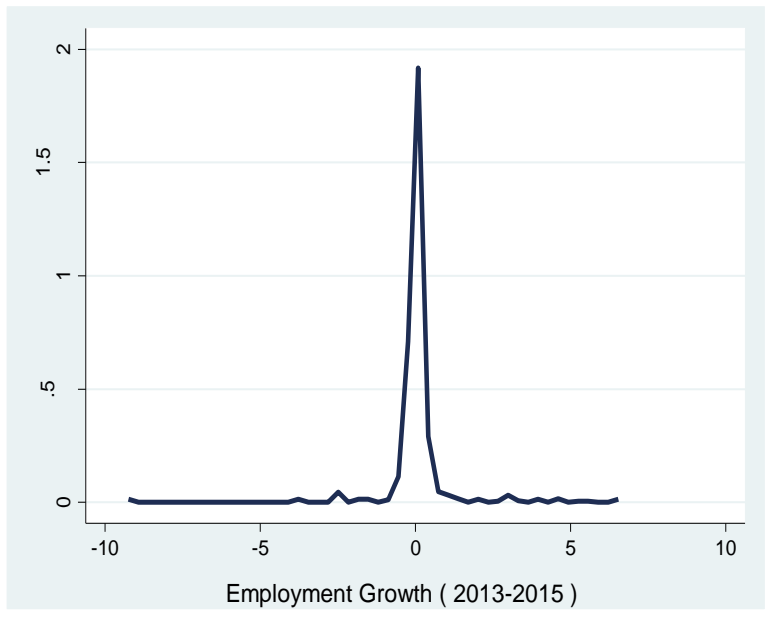

Source: Authors' Calculations.

Overall, the majority of firms are characterized by 0 employment growth, but the right tail suggests that employment growth is concentrated among a small number of firms, and within these there are visible growth differences. At the same time, there is a long left tail which implies that there is a higher number of firms that experienced negative employment growth.

Figure 1b: Employment Growth in Figure 1c: Employment Growth in Apparel Textiles
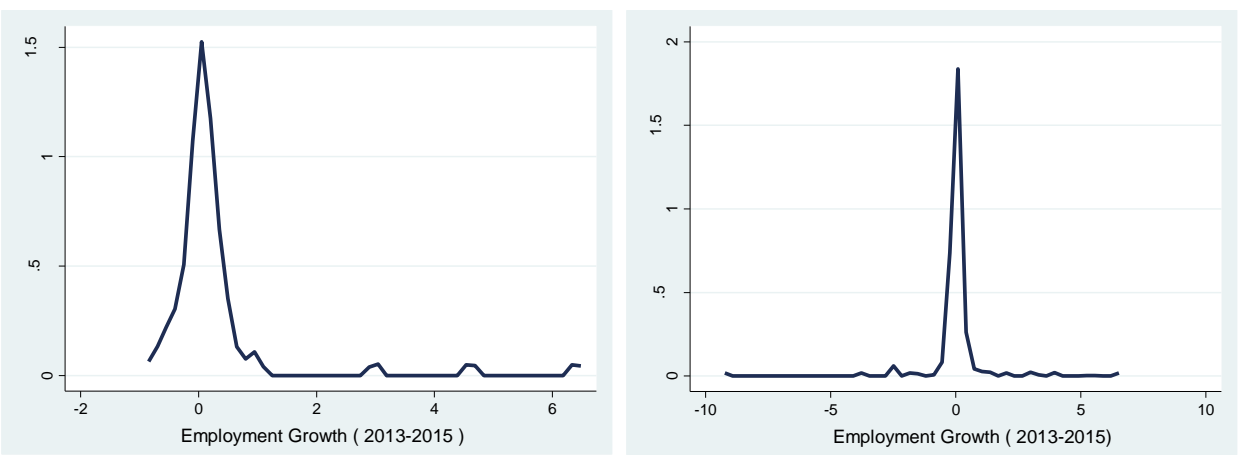

Source: Authors' Calculations.

Figures $1 \mathrm{~b}$ and $1 \mathrm{c}$ break the employment growth down into growth in the apparel and textile sectors respectively. While both distributions are centered around 0 growth, the significant difference that arises between the sectors is that the distribution of employment growth 
in the apparel sector contains a large positive tail while the distribution of employment growth in the textile sector has a large negative tail. So the apparel sector is characterized by more positive employment growth than the textile sector.

Moving to the distribution of sales growth amongst textile firms, we present the distributions for all the firms in Figure 2a and then the apparel firms and textile firms in Figures $2 b$ and $2 c$, respectively.

Figure 2a: Sales Growth (2013-2015)

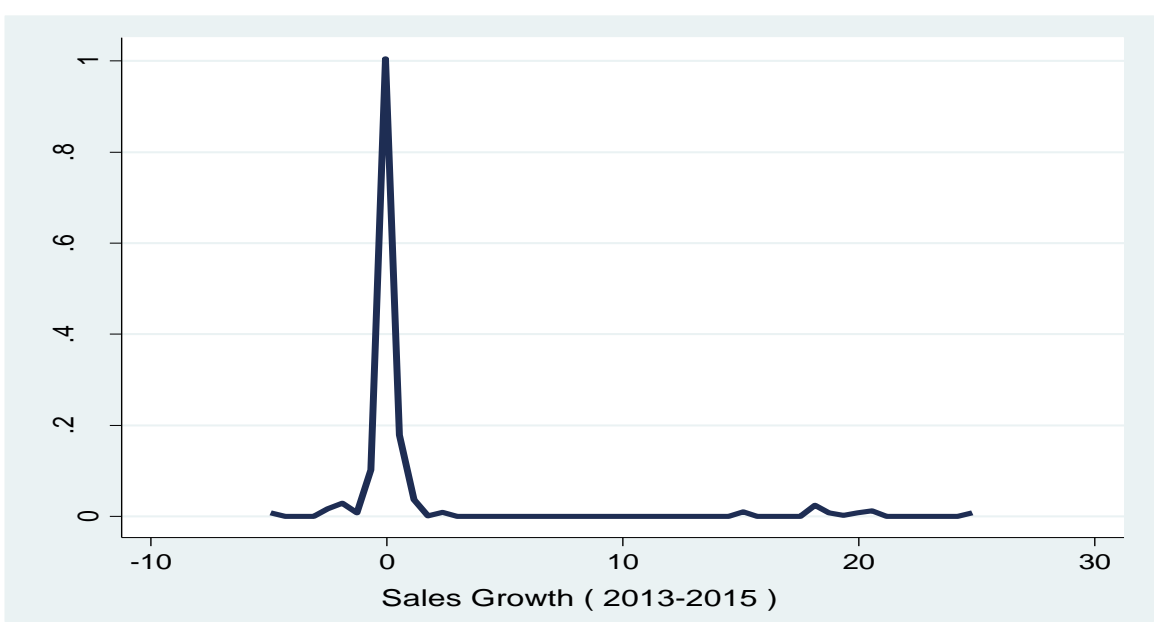

Source: Authors' Calculations.

Similar to the employment growth distribution, we find that the majority of firms experienced 0 sales growth, but at the same time the major difference in this case is that there is a large positive tail; in other words, there was a higher number of firms that experience positive sales growth and the growth differences between these firms were larger.

Figure $2 b$ and Figure $2 c$ respectively show the distribution of sales growth in the apparel and textile sub-sectors during 2013-2015. Unlike the case of employment, both sectors are characterized by a significant number of firms with positive sales growth, though the majority of firms in both sectors still experience 0 growth. 
Figure 2b: Sales Growth in Apparel Figure 2c: Sales Growth in Textile
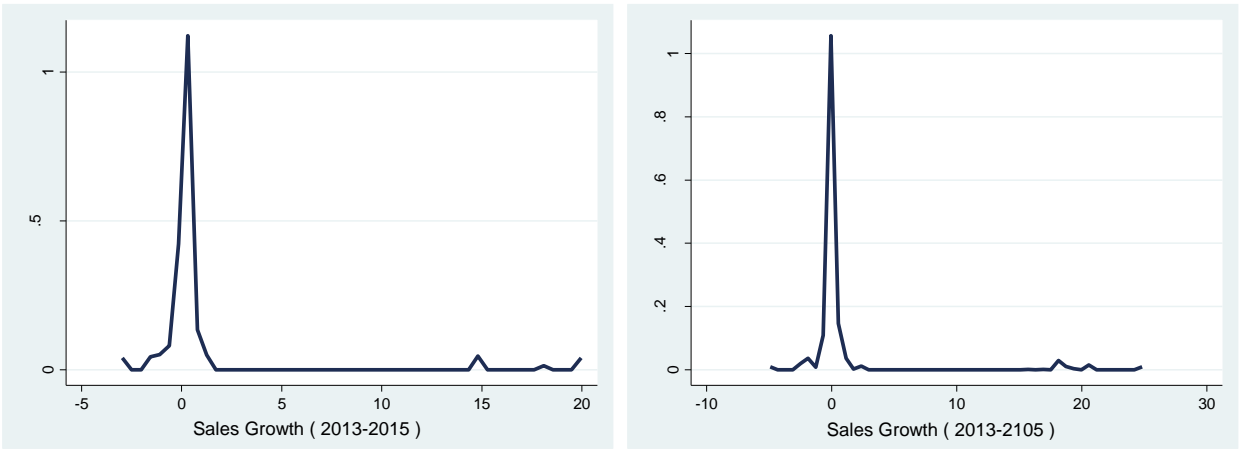

Source: Authors' Calculations.

\section{Correlates of Firm Growth}

In this section we provide some basic correlates for firm growth for the manufacturers in our sample. We start by looking at the correlates of employment growth and then we look at how small and young firms differ from other firms in terms of growth as well as how innovative firms differ from non-innovative firms in terms of growth. Finally, we put this all together and see how young, small and innovative firms differ from other firms in terms of growth. Table 3 presents the correlates of employment growth.

Table 3: Correlates of Employment Growth (2013-15)

\begin{tabular}{lcccccc}
\hline & Emp $_{2013}$ & Sales $_{2013}$ & Age $_{2013}$ & Exports $_{2013}$ & $\begin{array}{c}\text { R\&D } \\
\text { intensity }\end{array}$ & $\begin{array}{c}\text { Human } \\
\text { capital }\end{array}$ \\
\hline Empl growth & $-0.37^{* * *}$ & $-0.48^{* * *}$ & $-0.43^{* * *}$ & $-0.14^{* * *}$ & $0.10^{*}$ & $0.10^{* *}$ \\
\hline
\end{tabular}

Source: Authors' Calculations.

Note: ${ }^{* * *},{ }^{* *}$, and ${ }^{*}$ indicate statistical significance at $1 \%, 5 \%$, and $10 \%$ levels, respectively.

In line with much of the existing literature, we find that there is a negative correlation between firm size and employment growth (see Mansfield, 1962; Storey, 1994; Roper, 1997; Heunks, 1998; Freel, 2000; Coad et al., 2016; Wadho, Goedhuys, \& Chaudhry, 2019). Both smaller employment and smaller sales in 2013 are associated with higher employment growth. Similarly, there is also a negative association between firm age and employment growth suggesting that younger firms experience higher employment growth. Furthermore, we find that there is a negative association between a firm's export intensity and its growth. Firms with higher export intensity experienced lower employment growth. This could potentially be because export intensive firms may be older and larger and 
create less employment or may be because exporting leads to more automation and capital intensive technologies that reduce demand for labor.

We find that there is a positive correlation between a firm's innovation efforts and employment growth. Firms investing more on innovation grow faster. This could potentially be because firms who invest more on innovation are successful in introducing new products and processes that contribute to their expansion and result in more employment.

Finally, Table 3 reports a positive correlation between skilled labor and employment growth. Firms employing more skilled workers may be better able to absorb and implement new technologies and may also be more able to introduce new products and processes leading to business expansion and more employment.

The preceding correlation analysis provides clear evidence that smaller and younger firms are associated with more employment growth. In Table 4, we dig deeper and evaluate how different sized firms have shown growth in employment as well as how many net jobs have they created. Table 4 also reports how younger firms, and smaller younger firms tend to have greater employment growth and greater employment.

Table 4: Job Creation: Size and Age (2013-15)

\begin{tabular}{lcc}
\hline Types & $\begin{array}{c}\text { Mean growth in } \\
\text { employment in \% }\end{array}$ & $\begin{array}{c}\text { Mean net } \\
\text { employment creation }\end{array}$ \\
\hline Total sample & 9.7 & 24.78 \\
Small $(<50$ employees) & 26 & 11.96 \\
Medium ( $\geq 50$ but $<250$ employees $)$ & -3.5 & 00.18 \\
Large $(\geq 250$ employees) & -12 & 84.36 \\
Young $(<10$ years old) & 53 & 25.15 \\
Small and Young & 79 & 35.83 \\
\hline
\end{tabular}

Source: Authors' Calculations.

Results in Table 4 show that firm growth and employment creation vary substantially with firm size. While small sized firms experienced mean employment growth of 26 percent, both medium and large sized firms on average experienced negative growth. Similarly, the results in Table 4 show that younger firms experienced significantly more employment growth. While the mean employment growth in the sample was 9.7 percent, young firms experienced a mean employment growth of 53 percent. Focusing on firms that are both small and young i.e. combining the two attributes, one finds that the smaller younger firms experienced 
even higher employment growth. On average smaller, younger firms recorded mean employment growth of 79 percent which is 8 times higher than the average firm-level employment growth in our sample.

Another factor that is reported as being very conducive to employment growth is a firm's innovation behavior. Innovative firms introduce new products that create new markets and expand their shares in the existing market resulting in firm expansion. Expanding firms engaging in innovative processes may create more employment which leads to employment growth (see Martinez-Ros \& Labeaga, 2009; Miravete \& Pernías, 2006; Polder et al., 2009; Ballot et al., 2011; Wadho, Goedhuys, \& Chaudhry, 2019). So while process innovation is often associated with automation and cost-saving including reductions in labor, if process innovation leads to quality improvement in products, it can contribute to employment creation in a similar way as the introduction of new products does. Our data contains rich information on different innovative attributes of firms that we exploit to see if innovation is conducive to employment creation in our sample.

Table 5 shows the difference in employment growth for firms that are innovative versus firms that did not innovate over the period covered by the study.

Table 5: Job Creation Innovator Vs Non Innovators (2013-15)

\begin{tabular}{lcc}
\hline Types & $\begin{array}{c}\text { Mean growth in } \\
\text { employment in \% }\end{array}$ & $\begin{array}{c}\text { Mean net } \\
\text { employment creation }\end{array}$ \\
\hline $\begin{array}{l}\text { Total sample } \\
\text { Technological Innovation }\end{array}$ & 9.74 & 24.78 \\
Yes & 12.53 & 53.47 \\
No & 06.99 & -03.47 \\
Managerial innovation & & \\
Yes & 15.37 & 54.87 \\
No & 07.30 & 11.73 \\
Technological and Managerial innovation & & \\
Yes & 20.28 & 68.53 \\
No & 06.18 & 10.03 \\
RED investing & & \\
Yes & 17.45 & 59.56 \\
No & 04.81 & 02.54 \\
High RED intensity ( $\geq$ 5\%) & & \\
Yes & 36.65 & 82.80 \\
No & 02.37 & 8.90 \\
Continuous RED performing & & \\
Yes & 23 & 118.87 \\
No & 06 & -05.16 \\
\hline
\end{tabular}

Source: Authors' Calculations. 
The first observation noticeable from Table 5 is that, irrespective of the innovation proxy used, innovating firms on average experienced higher employment growth than the mean firm growth of 9.7 percent in the overall sample. Firms who introduced technological innovations experienced almost twice as much employment growth as the firms who did not introduce technological innovations. Similarly, technological innovators contributed around 54 new jobs whereas non-innovators shed jobs.

The same message comes through from the firms that performed managerial innovations: these firms experienced twice as much employment growth as the firms that did not perform these types of innovations. Firms that performed both technological and managerial innovations experienced three times the employment growth as firms that did not perform both of these innovations. This finding contributes to the larger debate on the role of innovation in firm performance in developing countries with low-tech industries. These results show that even though innovation in developing countries is characterized by an incremental nature or capabilities toward catch-up, it is still significantly correlated with firm performance in terms of growth and job creation.

We find even more striking differences when comparing firms investing in innovation, investing with higher intensity, and performing $R \& D$ on continuous basis. We find that firms that performed R\&D, firms that had high levels of R\&D investment intensity, and firms that performed $R \& D$ on a continuous basis experienced significantly higher employment growth. In contrast, firms who did not invest in $R \& D$, who did not invest enough, or who did not perform R\&D on continuous basis experienced very low employment growth.

There are also noticeable differences among innovators depending on which definition of innovation is used, which also sheds some light on the indicators used to capture innovation behavior in our particular context. Overall, firms who spent at least 5 percent of their turnover on innovation and firms who performed $R \& D$ on a continuous basis experienced much higher employment growth and net employment creation than any other innovative firm. In particular, firms who performed R\&D on a continuous basis increased net employment by 119 workers (on average) in comparison to firms not performing R\&D on a continuous basis who fired 5 (mean) workers (on average).

Finally, building on the growing literature on young innovative companies reported to be the major contributors to employment growth (see 
Veugelers, 2008; Czarnitzky \& Delanote, 2013; Schneider \& Veugelers, 2010), in Table 6 we look at the growth differences between YICs and young noninnovative companies. This analysis will also shed new light on the impact of innovation on job creation by small young enterprises. We combine size, age and innovation attributes to define YICs and then compare them with other innovative companies that are not small and young. We create three different types of young innovative companies by altering the definition of what it means to be innovative. In the first definition, $\mathrm{YIC}_{1}$, we define an innovative firm as an enterprise that introduced a technological innovation; in the second definition, $\mathrm{YIC}_{2}$, we define an innovative firm as one that performs $\mathrm{R} \& \mathrm{D}$ on a continuous basis; and in the third definition, $\mathrm{YIC}_{3}$, we define innovative firms as those that spent at least 5 percent of their turnover on innovation. Throughout, a firm is considered small if it employed less than fifty workers and young if it was less than 10 years old. We then compare the employment growth performance of these YICs versus innovative companies that are not young and small. Moreover, since we vary the definition of what constitutes an innovative firm, this analysis could also reveal which attribute of innovation is most impactful in terms of job creation in our context.

Table 6: Job Creation YICs Vs Non-YIC Innovators (2013-15)

\begin{tabular}{lcc}
\hline Types & Mean growth in employment in \% & Mean net employment creation \\
\hline YIC & & \\
Yes & 182.50 & 80.73 \\
No & -00.90 & 55.10 \\
YIC & & \\
Yes & 248.08 & 136.57 \\
No & 05.92 & 55.70 \\
YIC & & \\
Yes & 366.44 & 164.00 \\
No & -00.003 & 54.34 \\
\hline
\end{tabular}

Source: Authors' Calculations.

Note: Non-YIC innovator $=$ Firms who invest in innovation activities but are not YICs; YIC $_{1}$ $=1$ if age $<10 \&$ employment $<50$ \& Technological innovation $=1, \mathrm{YIC}_{2}=1$ if age $<10 \&$ employment $<50$ \& Continuous $\mathrm{R} \& \mathrm{D}=1, \mathrm{YIC}_{3}=1$ if age $<10 \&$ employment $<50$ \& with R\&D intensity $\geq 5 \%$ of turnover.

Table 6 shows some very striking differences in employment growth as well as in employment creation between the YICs and non-YIC innovators. While the YICs experienced extremely high employment growth, the non-YIC innovators were characterized by low or negative growth. Overall, this reinforces our hypothesis that the majority of growth that is taking place in our sample is because of the YICs. This also highlights the fact that even though innovation is conducive to employment growth as 
shown in the previous analysis, it is the combination of being both small young and innovative that is correlated with higher employment growth. This could potentially be due to the differences in innovation strategies of young firms versus more established incumbents. In order to compete with the incumbent firms, young enterprises engage more in radical innovations that are riskier but result in greater expansion and growth when successful. In a broader context, since YICs disproportionately contribute to job creation and employment growth, they could be very suitable candidates for targeted government support.

\section{Qualitative Analysis}

Finally, to give a richer interpretation to the findings, we approached two of YICs from our sample and conducted in-depth interviews with their managers to get additional insights on the relative importance of innovation for their employment and sales growth. Both companies have YIC status irrespective of the definition used for innovation. As the experiences of these two companies are very illustrative for the findings of the quantitative analysis, we present in a nutshell the main findings derived from the interviews. These two companies were chosen on the basis that they were both young and extremely innovative relative to other firms in the sample.

\section{Samad Textiles}

The first case study is Samad Apparel, located in Lahore. The company was created in 2007. It is part of a larger group, called Samad Rubber Works Private Ltd, a group that has since 1948 been active in the production of innovative rubber products for defense, including rubber boats, air mattresses with high insulation capacity, anti-mine shoes, backpacks for ammunition, life jackets and other war-related equipment and more recently diversified to other products such as the production of soccer balls. Building on our analysis above, it is useful to see a young firm like Samad textiles particularly focused on innovation-related activities and the impact that these activities had on its growth.

In terms of innovativeness, what makes Samad stand out from other firms in the sample is the company's heavy focus on product and process innovations combined with state-of-the-art managerial and organizational improvements. This is necessary as the company is serving international markets where customers require products with superior performance in combination with high fashion standards. Examples of its product innovations include denim jeans for bikers using thread used for bullet-proof jackets which is four thousand times more resistant than 
cotton In order to protect bikers from injuries and; waterproof breathable denim jeans for cold climates which are exported to Europe; a light-weight and easily folded jacket made of goose feathers for European; a waterproof breathable fire retardant jacket for disaster management purposes.

Samad Apparel's business model is export-oriented with major international customers including Takko, LPP, and Mango. For this, the company houses its own marketing, R\&D and fabrics department who all work together to develop up to 1500 to 2000 samples of new products every month that are then taken to customers for their feedback. This regular interaction of fashion designers with customers helps them to understand customer tastes and market demand. The company regularly sends its representatives to attend international fashion shows and exhibitions to learn new fashion trends, which helps them bringing novel products to international markets. While the development of fashionable and highly sophisticated new products in collaboration with customers is the most important driver of the company's success, process innovation in the form of investment in machinery capable of producing these products is needed and implemented as a simultaneous process.

The company's in-house R\&D department performs R\&D on a continuous basis and it considers this to be essential to the survival of any textile company in Pakistan. Product innovation is the basic driver of both sales and employment growth. Process innovation, encompassing the introduction of innovative machinery for reaching productive capacity to address demand, reduces the man-to-machine ratio, but this is largely compensated by increased demand for products, resulting in substantial, employment growth. The company seeks multi-skilled labor that can operate machinery and be flexibly shifted across job posts. For this purpose, it hires specialized people to train workers for the firm. The company invests in the skill development of its workers and offers them competitive wages along with basic health insurance and social security.

Apart from product and process innovations, Samad Apparel is very keen to improve management and workplace organization. The company reports state-of-the-art management systems including lean management, an Oracle based system, external auditing of its systems. These systems enabled workers to come up with the idea of taking a 30second break every two hours in the stitching department to clean machines and collect waste material.

The question arises of what is the impact of Samad's innovativeness on its growth. We find that Samad Apparel has grown spectacularly since 
its start and especially since 2013 when it began production of denim products. Between 2013 and 2015, sales doubled every 6 months to reach Rs. 627 million in 2015 while employment grew to 750 employees.

The example of Samad Textiles is a clear case of a successful young innovative firm that managed to enter international markets and boost sales and employment growth through a strong focus on innovative products combined with better processes, with a heavy investment in continuous $\mathrm{R} \& \mathrm{D}$, in line with the findings of the econometric analysis.

\section{Sarena Apparel}

The second case study is Sarena Apparel located in Sheikhupura. Like Samad, Sarena is part of a larger group called Sarena Industries. Sarena Industries is a textiles company specialized in weaving, dyeing, finishing, printing and manufacturing woven, non-denim fabric for apparel. The group has been producing clothing for the local market since 2001 mostly under own-brand names called Leisure Club, Minnie Minor, Kayseria and Bareeze. It also exports fabrics to many international brands. Initially the fabrics were exported to Bangladesh and India, where they were stitched. Serena Apparel was set up in 2014 with an aim to do the entire production of the garments for their own brands as well as for the major customers of Sarena Industries.

Like Samad, Sarena Apparel is convinced that its innovative approach lies at the heart of its successful expansion. Sarena Apparel cooperates with the R\&D department of Sarena Industries working on innovation in design and fabric. In 2014, the company attracted the attention of a major international buyer namely Primark, who placed an order of around 300,000 pieces of different garments. As a result of the order, the employment and sales performance of the firm peaked in the year 2015.

To accommodate to this order, 600 employees were hired, explaining the extreme employment growth performance of the company. To produce these products, the company made a huge investment in new automated machinery. The process innovation had an impact on labor quality as more qualified labor had to be hired. Primark also imposed social security payments for the workers as a condition to win the deal, which improved the employment contracts of workers.

Sarena differs from Samad in that the growth was actually a temporary yet exceptional performance, as such an employment level could not be sustained over time. The company is also more traditional in 
its management organization and management-to-worker relations. Ultimately, in 2017, Sarena Apparel was merged with Sarena Industries, its parent company. So this case study is more an example of a firm that grew steeply thanks to the innovative orientation of its group, but was taken over in a later stage by the same group.

Nonetheless, Sarena Textiles remains another example of how a small innovative firm can experience high rates of growth.

\section{Conclusions}

Firm growth is a critical feature of economic growth in developing countries and growth in textile sector firms is especially critical in the case of Pakistan. We find that the growth of firms in this sector (in terms of both employment and sales) is generally stagnant for a significant majority of firms and that positive growth is actually driven by a small number of firms.

We also move beyond the standard empirical analyses of innovation and growth to look at the case studies of two young firms that were heavily engaged in innovation. The impetus behind these case studies was to see what uniquely characterizes the young innovative firms in our sample, especially since the majority of the firms in the sector were old, noninnovative and experiencing little or no growth. The idea was also to show that it is still possible to be an innovative, high growth firm even in a sector that has existed for many decades and may have a tendency to stagnate.

When we look at the characteristics of these firms that drive growth, we find that they tend to be younger, smaller, and more innovative firms. This result is especially useful for policymakers trying to identify sectorspecific growth drivers since the focus had previously been to simply focus on firms of certain sizes or firms from certain sectors. Also in the context of Pakistan, there has been a heavy emphasis on providing incentives for older, larger textile manufacturers although this emphasis has failed to lead to any significant increases in exports and has also failed to spur Innovation by these older, larger firms which was required to produce higher value-added goods. Rather, previous policies seem to have led to stagnation in exports as well as a reliance of most manufacturers on producing low-value added goods without expanding into new products or improving product quality. Our results point to the need for policymakers to focus on firms that are not only small but rather on firms that are small and innovative if they want to promote higher employment and long-run economic growth. 


\section{References}

Audretsch, D. B., Coad, A., \& Segarra, A. (2014). Firm growth and innovation. Small Business Economics, 43(4), 743-749.

Ballot, G., Fakhfakh, F., Galia, F., \& Salter, A. (2011). The fateful triangle complementarities between product, process and organizational innovation in the UK and France (TEPP Working Paper, No 201105, TEPP-Institute for Labor Studies and Public Policies) [online]. Accessed September 20, 2015. Berulava and T. Gogokhia.

Coad, A., \& Rao, R. (2008). Innovation and firm growth in high-tech sectors: A quantile regression approach. Research Policy, 37(4), 633-648.

Coad, A. (2009). The growth of firms: A survey of theories and empirical evidence. Edward Elgar Publishing.

Coad, A., Segarra, A., \& Teruel, M. (2016). Innovation and firm growth: Does firm age play a role? Research Policy, 45(2), 387-400.

Czarnitzki, D., \& Delanote, J. (2012). Young innovative companies: The new high-growth firms? Industrial and Corporate Change, 22(5), 1315-1340.

Freel, M.S. (2000). Do small innovating firms outperform non-innovators? Small Business Economics, 14(3), 195-210.

Heunks, F. J. (1998). Innovation, creativity and success. Small Business Economics, 10(3), 263-272.

Mansfield, E. (1962). Entry, Gibrat's law, innovation, and the growth of firms. The American Economic Review, 52(5), 1023-1051.

Martinez-Ros, E., Labeaga, J.M., (2009). Product and process innovation: Persistence and complementarities. European Management Review, 6 (1), 64-75.

Miravete, E. J., \& Pernias, J. C. (2006). Innovation complementarity and scale of production. The Journal of Industrial Economics, 54(1), 1-29.

OECD, (2007). Eurostat-OECD Manual on business demography statistics, Paris: OECD. 
Pellegrino, G., Piva, M., \& Vivarelli, M. (2011). 25 How do young innovative companies innovate? Handbook of Research on Innovation and Entrepreneurship, 403.

Polder, M., Leeuwen, G. V., Mohnen, P., \& Raymond, W. (2009). Productivity effects of innovation modes (No. 18893). University Library of Munich, Germany.

Quatraro, F., \& Vivarelli, M. (2014). Drivers of entrepreneurship and postentry performance of newborn firms in developing countries. The World Bank Research Observer, 30(2), 277-305.

Schneider, C., \& Veugelers, R. (2010). On young highly innovative companies: Why they matter and how (not) to policy support them. Industrial and Corporate Change, 19(4), 969-1007.

Schumpeter, J. (1942). Creative destruction-Capitalism, socialism and democracy (Vol. 825). New York City, NY: Harper and Brothers.

Statistical Office of the European Communities. (2005). Oslo manual: Guidelines for collecting and interpreting innovation data (No. 4). Publications de l'OCDE.

Storey, D.J., \& Tether, B.S. (1998). New technology-based firms in the European Union: An introduction. Research Policy, 26(9), 933-946.

Veugelers, R. (2008). The role of SMEs in innovation in the EU: A case for policy intervention. Review of Business and Economics, 53(3), 239-262.

Veugelers, R. (2009). A lifeline for Europe's young radical innovators. Bruegel Policy Brief 2009/01, March 2009.

Wadho, W., \& Chaudhry, A. (2018). Innovation and firm performance in developing countries: The case of Pakistani textile and apparel manufacturers. Research Policy, 47(7), 1283-1294.

Wadho, W., Goedhuys, M., \& Chaudhry, A. (2019). Young innovative companies and employment creation, evidence from the Pakistani textiles sector. World Development, 117, 139-152. 